\title{
Obligation of Religious Practices for the Deaf
}

Nizaita binti Omar, Zulkifly bin Muda, Saiful Yuslizam bin Yakar, Manapiyah Maoti

To Link this Article: http://dx.doi.org/10.6007/IJARBSS/v11-i4/8764

DOI:10.6007/IJARBSS/v11-i4/8764

Received: 09 February 2021, Revised: 10 March 2021, Accepted: 29 March 2021

Published Online: 20 April 2021

In-Text Citation: (Omar et al., 2021)

To Cite this Article: Omar, N. binti, Muda, Z. bin, Yakar, S. Y. bin, \& Maoti, M. (2021). Obligation of Religious Practices for the Deaf. International Journal of Academic Research in Business and Social Sciences, 11(4), 1274-1283.

\section{Copyright: (c) 2021 The Author(s)}

Published by Human Resource Management Academic Research Society (www.hrmars.com)

This article is published under the Creative Commons Attribution (CC BY 4.0) license. Anyone may reproduce, distribute, translate and create derivative works of this article (for both commercial and non-commercial purposes), subject to full attribution to the original publication and authors. The full terms of this license may be seen at: http://creativecommons.org/licences/by/4.0/legalcode

Vol. 11, No. 4, 2021, Pg. 1274 - 1283

Full Terms \& Conditions of access and use can be found at http://hrmars.com/index.php/pages/detail/publication-ethics 


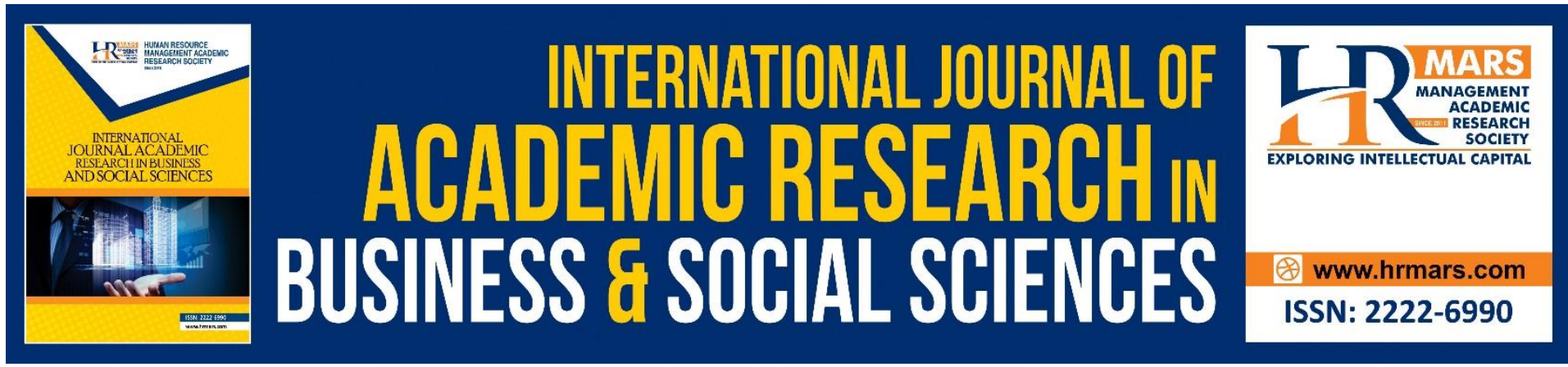

\title{
Obligation of Religious Practices for the Deaf
}

\author{
Nizaita binti Omar \\ Faculty of Islamic Contemporary Studies, Universiti Sultan Zainal Abidin (UniSZA) \\ Email: nizaitaomar@unisza.edu.my \\ Zulkifly bin Muda
}

Fatwa Department of Terengganu, Centre of Islamic Affair, Kuala Terengganu

Email: zulmuda66@gmail.com

Saiful Yuslizam bin Yakar

Faculty of Islamic Contemporary Studies, Universiti Sultan Zainal Abidin (UniSZA)

Email: saifulahyuslizam@gmail.com

Manapiyah Maoti

Academy of Islamic and Arabic Studies, Princess of Naradhiwas University

Email: maoti_pnu@yahoo.co.th

\begin{abstract}
Persons with disabilities are those who have long-term physical, mental or intelectual disabilities that may hinder them to give full and effective participation within a society. The hearing impaired are one of them with a specific incapacity of hearing. They refer to a community with hearing loss of above $90 \mathrm{~dB}$. At this level, they would need hearing aids or a mastery in sign language. Religious life is important to every living individual. It is a powerful catalyst for human beings to grow spiritually, physically and intellectually, and acts as a control force in their thoughts and actions. An individual who possesses high religious knowledge will adapt an organized and committed routine in their religious practices, thus resulting in strong work ethic, high family responsibilities and great quality of life. The question here is, do those categorized as hearing impaired have any obligation or duty to perform religious practices? This paper will analyze this matter based on the research done. Keywords: Persons with Disabilities, Hearing Impaired, Obligation, Religion, Quality of Life.
\end{abstract}

\section{Introduction}

Physically, persons with hearing impairment are no different from others. Their hidden disability is what makes them isolated in terms of interaction and communication that often get diverted from them (Zaharah, 2002). They are even more unfortunate than those of other disabilities since they lack verbal interaction with people. Sign language is the only medium that can help with this interaction. However, with it not being widely known and mastered, it 
is still obscure on how this issue of isolation can be overcome so their rights as human beings and citizens would not be compromised.

Religious development is a comprehensive, integrated and balanced development. It involves every physical and spiritual aspect of one's life, stemming from his practices as a servant of Allah (Syukri, 2014).

\section{Problem Statement}

Religion is an important aspect within every individual, including those with disabilities. It is a powerful catalyst in strengthening the spiritual, emotional, physical, and intellectual features of an individual. Living an ideal religious life leads to moderation of thoughts and actions. Life becomes more orderly, resulting in more commitment in religious practices and activities, more self-awareness, higher work motivation, more responsibility towards family, and higher drive to improve own life (Harris \& Enfield, 2003; George et al., 2000; Ayad, 2012; and Jones, 2016). Religious practices are a part of the manifestation of religion and belief of a person. In the Islamic context, religious practices must be the ones that stem from the Islamic law.

In society today, the hearing impaired or the deaf are often marginalized compared to those of other disabilities. They isolate themselves and they prefer to socialize only within their community, and this causes them to miss out on spiritual development (Zalilah, 2010). They tend to be in a solitary state due to their disability of communicating through regular means. This disability of hearing sound and interacting verbally impedes them from presenting and receiving information (Abdullah, 2002). The reality faced by the hearing impaired with their disability affects their communication with others on all matters including religion. This is what causes some people to presume that the religious obligation for the deaf is no longer valid and their status as mukallaf is dissolved.

In Malaysia, the statistics from the Department of Social Welfare show that citizens with hearing impairment reaches 43,788 in 2011 (as shown in Table 1). This is gathered based on their registration to the department. In the previous year, there are 39,824 of the hearing impaired registered with 23,693 of them are Malays (as shown in Table 2). If the definition of a Malay in Article 160 of the Constitution of Malaysia is employed here (Abdul Aziz \& Farid Sufian, 2004), it then also represents the number of those who were Muslims.

Table 1: Registration of Persons with Disabilities by Type of Disabilities, 2011

\begin{tabular}{lc}
\hline \multicolumn{1}{c}{ Type of Disabilities } & Number \\
\hline Visual impairment & 31,924 \\
\hline Hearing impairment & $\mathbf{4 3 , 7 8 8}$ \\
\hline Physical disabilities & 123,346 \\
\hline Learning disabilities & 134,659 \\
\hline Speech impairment & 725 \\
\hline Mental disabilities & 8,927 \\
\hline Others & 15,834 \\
\hline
\end{tabular}

Source: Statistics of the Department of Social Welfare 
Table 2: Registration of Persons with Hearing Impairment by Ethnicity, up until 2010

\begin{tabular}{lc}
\hline \multicolumn{1}{c}{ Ethnicity } & Number \\
\hline Malay & $\mathbf{2 3 , 6 9 3}$ \\
\hline Chinese & 9,423 \\
\hline Indian & 3,505 \\
\hline Natives of the Peninsula & 77 \\
\hline Natives of Sabah & 2,063 \\
\hline Natives of Sarawak & 668 \\
\hline Others & 395 \\
\hline & Total \\
\hline
\end{tabular}

Source: Statistics of the Department of Social Welfare

\section{Literature Review}

There are several researches done on issues the hearing impaired face in Malaysia. One of them is by Siti Ramna (2018) who focuses on the challenges and obstacles encountered by them, with the prominent issue being communication with family and community who are not familiar with the sign language. This affects their education as well when most teachers, especially those who teach Islamic Studies, are incompetent in communicating with students with hearing impairment. Norakyairee (2019) in his writing also expresses his concern on teaching and learning approaches for the subject of Islamic Studies escpecially to students with special needs that still seem weak and need to be seriously handled. In addition, Nik Hassan (2016) finds that programs of religious studies that are held for the hearing impaired today still mostly depend on the instructors' competency on sign language without the provision of relevant technological equipments. All these difficulties bring ineffectiveness to their learning which then lead to them failing to live a religious life, thus getting involved with immoral acts (Nur Salimah, 2011).

There are also a number of studies done on the level of religion and $d a^{\prime} w a h$ among the hearing impaired. A study by Abd Hakim (2018) reveals that the hearing impaired are among those who are spiritually behind. This is inferred based on their achievement in the subject of Islamic Studies through formal assessments. Their level of religious knowledge is also weak and most of them do not perform religious practices in the correct manner. This is supported by Mohd Huzairi (2019) whose study shows that knowledge on fardhu ain (obligatory acts) among the students with hearing impairment is poor. The statistics of the results of Penilaian Menengah Rendah (Lower Secondary Assessment) in Terengganu in 2016 confirms this assertion. 
Table 3: Results of Penilaian Menengah Rendah (Lower Secondary Assessment) in Terengganu, 2016

*Subject: Islamic Studies

This study will utilize previous studies in an attempt to address the presented issues. They need to be given special attention and care by all parties, including parents, teachers, society, and the authorities, particularly the Malaysian Ministry of Education (Abd Hakim, 2018).

\section{Research Methodology}

In general, this research uses the methodology of library research with qualititative approach of both exploratory and descriptive. Exploratory approach uses the formula of investigative focus to give a clue on necessary identified results (Sabitha, 2005). This research applies the content analysis technique in examining the data, taken from journals, seminar proceedings, scientific magazines, printed media, electronic media, internet and others.

This research uses descriptive approach which is very selected issue is analyzed, explained, argued and reviewed by the researcher to obtain a verdict that is relevant and fitting with the Islamic law and capable of giving the best solution to the issues encountered. Data are then processed, organized and analyzed until conclusion is reached.

Findings and Research Discussion

\begin{tabular}{|c|c|c|c|c|c|c|c|c|c|c|c|c|c|c|}
\hline \multirow{2}{*}{ NO. } & \multirow{2}{*}{ SUBJECT } & \multirow{2}{*}{$\begin{array}{c}\text { NO. OF } \\
\text { STUDENTS }\end{array}$} & \multicolumn{2}{|c|}{ A } & \multicolumn{2}{|c|}{ B } & \multicolumn{2}{|c|}{ C } & \multicolumn{2}{|c|}{ D } & \multicolumn{2}{|c|}{ E } & \multicolumn{2}{|c|}{$\mathbf{F}$} \\
\hline & & & No. & $\%$ & No. & $\%$ & No. & $\%$ & No. & $\%$ & NO. & $\%$ & No. & $\%$ \\
\hline 1 & $\mathrm{BM}(\mathrm{T})$ & 19 & 0 & 0.0 & 0 & 0.0 & 0 & 0.0 & 0 & 0.0 & 4 & 21.1 & 15 & 78.9 \\
\hline 2 & $\mathrm{BI}(\mathrm{T})$ & 19 & 0 & 0.0 & 0 & 0.0 & 0 & 0.0 & 0 & 0.0 & 2 & 10.5 & 17 & 89.5 \\
\hline 3 & SEJ & 19 & 5 & 26.3 & 7 & 36.8 & 3 & 15.8 & 2 & 10.5 & 0 & 0.0 & 2 & 10.5 \\
\hline 4 & GEO & 19 & 7 & 36.8 & 8 & 42.1 & 1 & 5.3 & 0 & 0.0 & 1 & 5.3 & 1 & 5.3 \\
\hline 5 & $\mathrm{PI}^{*}$ & 19 & 0 & 0.0 & 0 & 0.0 & 0 & 0.0 & 0 & 0.0 & 3 & 15.8 & 16 & 84.2 \\
\hline 6 & MAT & 19 & 0 & 0.0 & 0 & 0.0 & 0 & 0.0 & 3 & 15.8 & 5 & 26.3 & 11 & 57.9 \\
\hline 7 & SN & 19 & 0 & 0.0 & 0 & 0.0 & 0 & 0.0 & 0 & 0.0 & 0 & 0.0 & 19 & 100.0 \\
\hline 8 & $\mathrm{KH}(\mathrm{T})$ & 11 & 0 & 0.0 & 0 & 0.0 & 6 & 54.5 & 5 & 45.5 & 0 & 0.0 & 0 & 0.0 \\
\hline 9 & $\mathrm{KH}(\mathrm{E})$ & 8 & 0 & 0.0 & 1 & 12.5 & 3 & 37.5 & 2 & 25.0 & 2 & 25.0 & 0 & 0.0 \\
\hline
\end{tabular}

Following are the detailed reviews on laws regarding the obligation of religious practices for the hearing impaired.

\section{Status of the Hearing Impaired from the Islamic Perspective}

Islam is a religion of nature that is aimed to satisfy all human needs and desires. Every person deserves to adapt Islam as their way of life. Islam never divides its people based on their physical abilities. This is as emphasized by the Prophet:

"Indeed, Allah never judges you based on your appearance and property, but on your heart and actions."

Narrated by Muslim and Ibnu Majah

From the hadith above, it is clear that those with physical disabilities such as the hearing impaired deserve similar honour and status as others. As Islam grants a very high status to 
those who are pious, the efforts to earn the piety are demanded to all Muslims including the physically disabled. This is as stated in the al-Quran:

"Verily the most honoured of you in the sight of Allah is (he who is) the most righteous of you."

Al Hujurat: 13

Islam also cherishes activities that have to do with seeking knowledge, be it done by a normal Muslim or a disabled Muslim. Effective knowledge seeking will only be achieved through the process of learning. It is demanded in Islam as stated in a hadith:

"Seeking knowledge is obligated to every Muslim."

Narrated by Ibnu Majah

Learning and acquiring knowledge are one of the basic human rights. In Islam, persons with disabilities are individuals whose rights to knowledge can never be denied. It was once narrated that one day, the Prophet who was occupied with the da'wah (preaching) to the Quraysh leaders, was approached by Abdullah bin Ummu Maktum who was visually impaired. Seeing Abdullah, the Prophet turned his face away from him to focus on the leaders. Upon this occasion, Allah revealed verses 1 to 11 from Surah 'Abasa, stating that:

"He (Prophet Muhammad) frowned and turned away because there came to him the blind man (interrupting). But what could tell thee but that perchance he might grow (in spiritual understanding)? Or that he might receive admonition, and the teaching might profit him? As to one who regards himself as selfsufficient, to him dost thou attend. Though it is no blame to thee if he grows not (in spiritual understanding). But as to him who came to thee striving earnestly, and with fear (in his heart), of him wast thou unmindful. By no means (should it be so)! For it is indeed a message of instruction."

Although the occasion above is about a visually impaired person, it can be generalized to those with other disabilities as well. This is in line with the method that is employed by most scholars of hermeneutics which is al ibratu biumum allafaz la bi khususi sabab (moral is perceived with a general conception, not in the specific reason of a verse's revelation) (Muhammad Abu Shahbah, 1992). We can conclude from the revelation above that the hearing impaired who are Muslims can in no way be denied of the obligation of seeking knowledge and understanding the religion. There is no exception for them in executing the obligation and performing religious practices as stated in the al-Quran.

\section{Definition of taklif and its conditions}

According to Umar (2005), the word taklif comes from an Arabic word which means a responsibility or obligation to do something that is originally a burden or a difficulty. It can also be defined as an order or command to perform something difficult.

There are three creatures whose taklifs are accepted by Allah which are angels, men and jinn. However, not all men are accountable with it. Men who are considered mukallaf (accountable one) are only those who are mature (have hit puberty), sane and informed of the teaching of 
Islam. Islamic scholars agreed that every command of Allah is only applicable to creatures of sound mind, as stated in a hadith:

"Records of sins are lifted from three groups of men: the insane until they recover, the asleep until they are awake and children until they dream."

(Narrated by Abu Daud from Aisha)

On that account, it is safe to conclude that those who are insane, asleep and immature (have not reached puberty) are excluded from the category of mukallaf for the absence or lack of sanity. They might have basic judgement on the context of a verse but they would not be able to provide a deep insight in it. They would not be able to differentiate a command from a prohibition and rewards from sins. They can be equated with immature children who do have an understanding of something, yet it is not complete (Umar, 2005). Hence, based on the hadith above, the hearing impared, specifically the deaf, are not exempted from taklif as long as they are sane and mature since they can still understand the verses of command and prohibition though the sign language.

There are still questions about the dilemmas that persons with hearing impairment might face in their process of understanding religion. The common issues are typically related to the effectiveness of communication in the teachings of obligatory acts (prayers, fasting, pilgrimage, etc.), the translation of al-Quran, listening to Friday sermons, performing hajj (pilgrimage) in Mecca and other practices that involve verbal interaction that do not only concern them as the receiver but also religious members as the explainer.

Generally known, the hearing impaired can still interact and communicate using the sign language, so there should be no restriction for them to learn and study about Islam as long as they are of sound mind. Possessing sanity of mind means having the same responsibility as other Muslims. Thus, having a hearing impairment alone without losing any mental capability does not abolish a person's taklif or obligation to perform religious duties.

The status of the hearing impaired as mukallaf is established based on the fatwa agreed by Islamic jurists. Among them is Aziz (1992), who affirmed that even if a person is deaf and mute at the same time, or deaf and blind at the same time, he is still considered mukallaf within the scope of his capabilities (for he might not be capable to understand to the fullest extent the teaching of Islam). The fact that he is still capable of understanding Islam by certain means deems him as mukallaf.

\section{Religious Practices for the Hearing Impaired}

The basis of religious practices, such as prayers, for individuals who cannot hear and say words is observing and following others'movements. They are demanded to perform the acts based on their capabilities as Islam never intends to burden its people in any way.

The general formula in Sharia is he who is not capable of performing an obligatory act will have the obligation lifted from him, although he is still required to execute it according to what he is capable of. This is based on the following verses:

"So fear Allah as much as ye can." 
"On no soul doth Allah place a burden greater than it can bear."

"Allah doth not wish to place you in a difficulty."

Al-Baqarah: 286

Al-Maidah: 6

"Allah intends every facility for you; He does not want to put you to difficulties."

Al-Baqarah: 185

A hadith from the prophet stated that:

"When I command an affair, do it according to your ability."

(Muttafaq 'alaih)

Based on the justification above, it can be concluded that for those who cannot hear and speak, ergo cannot read, it is lifted from them the obligation to perform acts that involve reading and reciting. For example, the way they perform their prayers would be different from others for they cannot recite al-Fatihah which is one of the requirements for a complete salah (prayer). How are they going to read and memorize al-Fatihah if they cannot listen and vocalize the verses, even the letters?

This, nonetheless, is not a big issue since the concept of a prayer in terms of its meaning, requirements, and obligation can be taught to the hearing impaired using the sign language. Al-Fatihah, for instance, can be learned and read non-verbally, and if it is still impracticable, they are allowed to just mime some zikr during the period of the al-Fatihah recitation. If they still cannot do it, they can just stay silent during the interval (Al-Sharqawi, n.d.).

However, those with hearing impairment should not take the easy way out and be content with mere mention of Allah as a substitution of al-Fatihah in the prayers as explained above. They should still attempt to improve and correct their religious acts as well as their general Islamic knowledge.

\section{Obligation of Spreading Islam to the Hearing Impaired}

Islamic missionaries need to put the hearing impaired as one of their targets to spread Islamic teaching to. They are entitled to knowledge and guidance as much as people with no disability are. They deserve to find their ways to the right path and savour the sweetness of faith. However, these ways would mostly be closed if the missionaries are not well-prepared with appropriate skills, plans and drive. Sirat al-Mustaqim or the straight path, i.e. Islam, is the ultimate goal that must be achieved by every Muslim, as stated in the al-Quran.

It is in fact harder to spread knowledge or even just to interact to individuals with hearing impairment compared to those who are normal but this should not be made an excuse or an issue to abandon and not carry out our duty as Muslims to share knowledge to them. It is true that they are somewhat different from others, but with assistive devices that are widely available today and skills such as sign language, it is possible for Islamic missionaries with high commitment and full participation to reach to them so they would not be left in ignorance (Zaydan, 1976).

Fathi Yakan (2001) also agrees that those with physical disabilities should be included in activities of preaching and spreading knowledge just like any normal person is. They must be educated, guided and informed of religious teachings until they do what is obliged to them and avoid what is forbidden since they too are considered mukallaf and should be compelled to Islamic law (Ibn Aqil, 1958). 
Futhermore, these days, external influences give a lot of negative impacts to the youth. Promiscuity and substance abuse are two of the most common issues for teenagers today. Openness of the modern world adds fuel to the fire of their curiousity and sparks their association to the negative behaviours.

In the effort of changing men to the better, we need to remind and advise them as well as exemplify good and proper behavior. This should apply those with hearing impairment as well. It is frequently heard that they tend to act against the Islamic law, and we should ask ourselves why it happens. Is it because of their ignorance of the law? If so, it is safe to assume that there is not enough transfer of knowledge taken place from us, specifically the Islamic missionaries, to them. This is worrying since faith and knowledge are what guide and hinder us from slipping into the acts that are against the Sharia.

\section{Conclusion}

Every Muslim is given a responsibility for their actions that will be disputed in the hereafter. This applies to the hearing impaired as well. They are not in any way exempt from the obligations of Islam. However, they are given flexibility to execute the obligations, especially the obligatory acts like prayers and al-Quran recitation, according to their capabilities. Discussion among the Islamic jurists clearly arbitrates that they still have the obligation of living a religious life and performing religious practices but within the limit of their capabilities.

To help them go through this obligation, all parties should have a sense of responsibility to facilitate their journeys as this is a part of our $d a^{\prime}$ wah to them. We should keep navigating until we discover the best method(s) that we can use to get the optimum effectiveness in reaching out and transferring knowledge to them. This is in accordance with the figh concept which is "if an obligation is not complete without it, then it becomes obligatory" (Taqiuddin, 1997).

\section{Acknowledgement}

Highest appreciation is given to Universiti Sultan Zainal Abidin for the sponsor provided for this research through the Translational University Grant (TUG) UniSZA/TUG/2019/03 (R0063). This is the first research done since the grant started.

\section{Corresponding Author}

\section{Nizaita Omar}

Faculty of Islamic Contemporary Studies, Universiti Sultan Zainal Abidin (UniSZA), Gong Badak Campus, 21300 Kuala Nerus, Kuala Terengganu, Terengganu, Malaysia.

Email: nizaitaomar@unisza.edu.my

\section{References}

Al Quran

Akta Orang Kurang Upaya 2008. (Akta 685). Majlis Kebangsaan bagi Orang Kurang Upaya dalam Laman Web Jabatan Kebajikan Masyarakat Malaysia, Kementerian Pembangunan Wanita, Keluarga dan Masyarakat. 
Al Baz, A. A. (1992). Majmu' Al Fatawa Wa Maqalat Mutanawwi'ah. Riyadh: Maktabah Al Arif

Al Futtuhi, T. M. (1997). Syarh Al Kaukib Al Munir. s.l.: Maktabah Al Abikan.

Al Syarqawi, A. H. (n.d.). Hasyiah Al Syarqawi. Beirut: Dar Al Ihya' Al Turath Al Arabi.

Ali, A. (1993). Fathul Bari (Vol. 1). Lebanon: Dar Al-Fikr.

Awang, M. H. (2017). Penghayatan Fardu Ain Remaja Pekak Di Malaysia (Tesis Doktor Falsafah). Kuala Lumpur: Universiti Malaya.

Ayad, A. (2012). "Effect of Spirituality on Health: An Islamic Perspective". Available online at: http:// www.amiraayad.com/my-blog/effect-of-spiritualityon-health-an-islamicperspective [accessed in Universiti Sultan Zainal Abidin, Malaysia: January 16, 2021].

Bari, A. A., \& Shuhaib F. S. (2004). Constitution of Malaysia: Text and Commentary, Kuala Lumpur: Pearson Prentice-Hall

Basmeih, A. (2000). Tafsir Pimpinan Ar-Rahman kepada Pengertian Al-Quran. Putrajaya: Department of Islamic Development Malaysia.

Harris, A., \& Sue, E. (2003). Disability, Equality, and Human Rights: A Training Manual for Development and Humanitarian Organisations. UK [United Kingdom]: Oxfam GB. Available online also at: http://hpod.org/pdf/disability-equalityoxfam.pdf

Jones, J. (2016). "A Qualitative Study Exploring How Occupational Therapists Embed Spirituality into Their Practice". Unpublished Doctoral Thesis. UK [United Kingdom]: University of Huddersfield. Available online also at: http://eprints. hud.ac.uk/ id/eprint/ 27857/1/Revision_copy_of_thesis_Final23 [accessed in Universiti Sultan Zainal Abidin, Malaysia: January 16, 2021].

Kathir, I. (2006). Tafsir Al-Quran Al-Azim (Vol. 1). Lebanon: Dar Al-Kutub Al-Ilmiyah.

Khamaruddin, S. R. (2018). Analisis Keperluan Pembangunan Bahasa Isyarat Malaysia bagi Terminologi Ibadah. International Journal for Studies on Children, Women, Elderly and Disabled, Vol. 4 (June) 2018 65-68

Mansor N. S. (2011). Penghayatan Agama Golongan Pekak di Kuala Terengganu (Tesis Doktor Falsafah). Bangi: Fakulti Pengajian Islam, Universiti Kebangsaan Malaysia

Marican, S. (2005). Kaedah Penyelidikan Sains Sosial. Petaling Jaya, Selangor: PearsonPrentice Hall.

Raus, N. M. (2019). Pendidikan Agama Dalam Kalangan OKU: Isu dan Cabaran Semasa. Kertas Kerja Seminar Kesedaran Pendidikan KAFA kepada OKU pada 9 April 2019 di Institut Latihan Islam Malaysia, Bangi.

Sabitha Marican. (2005). Kaedah penyelidikan sains sosial. Petaling Jaya, Selangor: Pearson

Sabitha Marican. (2005). Kaedah penyelidikan sains sosial. Petaling Jaya, Selangor: Pearson

Salleh, M. S (2014). Islamisasi Pemikiran Pembangunan. Prosiding Seminar Islamisasi Pembangunan. Medan, Indonesia: Universitas Muhammadiyah Sumatera Utara.

Seman, N. H. (2016). Analisis Permasalahan Pelajar Cacat Pendengaran dalam Pembelajaran Mata Pelajaran Pendidikan Islam di Malaysia. Jurnal IImi Jilid 62016 105-124

Shahbah, M. A. (1992). Al Madkhal Li Dirasat Al Quran Al Karim. Cairo: Maktabah Al Sunnah.

Sulaiman, S. Z. (2003). Text of Speech on Celebrating the International Deaf Day.

Yusof, M. Z. (2005). Sebutan Allah sebagai Ganti al Fatihah dalam Solat. myMasjid. http://www.mymasjid.net.my/?mod=forum_content\&mod2 $=366088$ [accessed in Universiti Sultan Zainal Abidin, Malaysia: January 16, 2021]. 